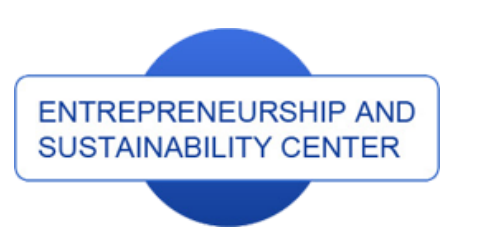

Publisher

$\underline{\text { http://jssidoi.org/esc/home }}$

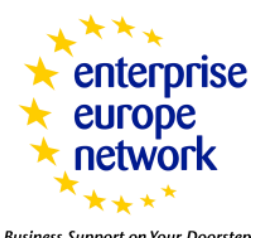

Business Support on Your Doorstep

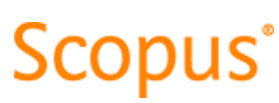

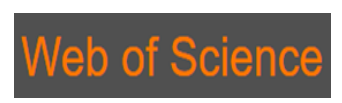

Clarivate
Analytics

\title{
THE DOCTRINE OF APPARENT AUTHORITY AS A PRECONDITION FOR SUSTAINABLE BUSINESS
}

\author{
Vaidas Jurkevičius ${ }^{1}$, Yuliia Pokhodun ${ }^{2}$ \\ 1,2 Mykolas Romeris University, Ateities st. 20, 08303, Vilnius, Lithuania \\ ${ }^{1}$ Vilnius Gediminas Technical University, Sauletekio av. 11, 10223, Vilnius, Lithuania \\ E-mails: ${ }^{1}$ vaidas.jurkevicius@mruni.eu $;{ }^{2}$ yulia.pokhodun@icloud.com
}

Received 20 June 2018; accepted 16 November 2018; published 30 December 2018

\begin{abstract}
In the light of modern commercial relationships, the doctrine of apparent authority plays an important role in ensuring the sustainability of business. Where the business undertaking is a large and complex one, it would be difficult and inconvenient for a person or legal entity to communicate every transaction with the agent. Thus, an agent's effective powers in dealing with third parties may extend to transactions that he was not authorized to undertake by the principal. Such situations are usually characterized as apparent authority. The difficulty with this type of authority lies in the lack of control on the part of the principal which entails certain questions of liability of either the agent or the principal. Even though the third party has to check the agent's authority, he cannot know about all the details of the agent's internal authorization. Therefore, there is always a risk that the agent was not authorized to act. This article is deemed to provide a comprehensive analysis of the doctrine of apparent authority from a comparative perspective. A conclusion is made that the doctrine is an efficient mean of apportioning the risk of liability for agent's unauthorized act between the principal and the third party with individual factors determining who must bear liability it in every specific case.
\end{abstract}

Keywords: agent; unauthorized agency; apparent authority; manifestations of authority; estoppel doctrine; sustainable business

Reference to this paper should be made as follows: Jurkevičius, V.; Pokhodun, Y. 2018. The doctrine of apparent authority as a precondition for sustainable business, Entrepreneurship and Sustainability Issues 6(2): 649-661. http://doi.org/10.9770/jesi.2018.6.2(13)

JEL Classifications: K12, K20

Additional disciplines: law

\section{Introduction}

The common law approach is based on "externalized" theories, which state that agency situations should be explained from the third party's point of view. This means that common law fails to make a proper distinction between the internal relation between principal and agent and the external relation between the agent and third parties, but simply involves the contract of two persons. Undeniably, the common law theory of identity has certain problems but in the perspective of modern commercial life, "external" approach appears to be practical and more justified from the standpoint of the needs of reality, than the abstract method of separation. 
The International Journal

ENTREPRENEURSHIP AND SUSTAINABILITY ISSUES

ISSN 2345-0282 (online) http://jssidoi.org/jesi/

2018 Volume 6 Number 2 (December)

http://doi.org/10.9770/jesi.2018.6.2(13)

Most agency relationships arise from agreement of a certain form between the principal and the agent. In other words, the principal and agent have to "agree about the creation of the relationship" and to confer on the agent certain "powers to act on the principal's behalf in relations with third parties" (Fridman 1996). This definition should be added with the mentioning of liability, which can be created by agents in respect of their principals under tort and criminal law.

Authority in general constitutes the agent's power of a special sort to affect the principal's legal relations with third parties in such a way as if he had done the act himself. However, the notions of authority and power should be distinguished (Powell 1951). Authority carries the image of a paradigm justifying a legal result, whereas "power" is neutral and simply states the result regardless of the justification for it (Reynolds 2010; Finogentova et al. 2028).

In agency doctrine, actual (real) and apparent authorities are usually discussed. The major difference between apparent and actual authority lies in justification of the agent's acts in relation to the principal. In contrast to apparent authority, real authority is more than just a legal power "looking out" (posse) an agent, also there is a privilege "looking in" (licere) to the lawfulness of his conduct. The power and privilege are supported by the principal when the agent performs actions with actual authority, while, in the case of apparent authority, the agent has only an external legal power to act without corresponding internal principal's justification (Müller-Freienfels 1957).

Apparent authority describes a situation when the negotiation of an urgent issue with a principal is impossible the agent might have only the appearance of authority, but no actual authority to act on behalf of the principal. Diplock L. J. in the case Freeman \& Lockyer v Buckhurst Park Properties (Mangal) Ltd (1964) rightly noted that in ordinary business dealings the contractor at the time of entering into the contract could hardly ever rely on the agent's "actual" authority. Information on the authority must flow either from the principal or from the agent, or from both, as only they know about the scope of the agent's actual authority. The contractor knows only what he is being told, which may or may not be true. Ultimately, he relies either upon the principal's representation (apparent authority) or upon the agent's representation (warranty of authority).

Therefore, apparent authority is an essential part of the unauthorized agency, since there is always a risk that the principal would not approve the agents act and it would be considered as performed without a proper authority. Nevertheless, the agent is still capable to bind the principal by a contract with a third party, if the latter entered into such contract with the agent in reliance on the principal's representation.

Also, the difference between apparent and actual authority is that actual authority arises from the principal to the agent, while apparent authority flows directly to the third party from the principal. Nevertheless, these types of authority very often overlap and cause the impossibility to decide whether parties rely on apparent or actual implied authority. Lord Denning in Hely-Hutchinson stated that "apparent authority...often coincides with actual authority. Thus, when the board appoints one of their members to be managing director, they grant him not only implied authority, but also with apparent authority to do everything that falls within the usual scope of that office. All others, however, are entitled to assume that he possesses usual authority of a managing director" (HelyHutchinson v. Brayhead Ltd 1968).

In certain circumstances, the scope of an agent's apparent authority may be equivalent to the scope of agent's actual authority, in other words, to the extent the agent reasonably believes in having the authority to act granted to him on the basis of his position or status by the principal (Restatement (Third) of Agency 2006). In addition, the extent of the agent's apparent authority created by estoppel largely depends upon the contents of the acts done by the principal to the third party who relies on representation. 
The issue of legal foundation of the doctrine of apparent authority is also marked with disparity, since the doctrine of apparent authority is comparatively new both in common and continental law. For this reason, there is no unified approach regarding it even within one legal system and long-lasting discussions of scientists from different countries are held regarding the question whether apparent authority should be based on estoppel or the objective theory of contract.

The aim of this article is to analyse the concept of apparent authority within the doctrine of agency, its constituencies and ways of treatment in different jurisdictions. Controversies regarding the basis of apparent authority are presented in the current research since even countries within one legal system hold different approaches toward the contract or estoppel basis of apparent authority. Since the issue of authority is problematic also in continental legal system, the article also provides a comparative legal research of this issue, which is particularly important in order to ensure the possibility of full realization of the agency relations.

This study is based on the qualitative methodology approach and principles. The paper is also based on methodological regulations of studies of law, matching ideas of theories of normative and case law. The main data collection method used during the study was method of conceptual analysis when analysing the existing conceptual legal framework of the doctrine of apparent authority. Taking into account the character of the study, the most important data analysis method in this paper is comparative when revealing divergences in the legal systems concerned. The reference point of this study is legal regulation of the doctrine of apparent authority in countries with continental law system and common law system. Regulation in an article established in this legal act is compared to provisions of international instruments of unification of private law (the so-called soft law) and law of civil law countries.

\section{Legal foundation of the doctrine of apparent authority}

It is not easy to find the legal foundation of apparent authority. There is a long-standing discussion whether apparent authority is a true authority or whether it creates a liability for the principal based on estoppel (Cook 1905). If it appears to be a class of authority, it becomes similar to actual authority, a power of an agent to bind his principal by the contract with the third party. In this case, both parties are bound and the principal does not have to authorize the agent's act.

English view on apparent authority later followed by UNIDROIT Principles (2010) differs greatly from the American-law position as the former regards the concept of estoppel as the basis (Bowstead 2014) and the latter sticks to objective theory of agency, which is directly derived from the objective theory of contract. A disparity has also marked the development of the doctrine within Europe itself. Continental leading approach is that the concept of apparent authority is based on the objective theory of agency, which is directly derived from the objective theory of contract.

The legal term 'estoppel' means that a person, who has let another person believe that a certain state of affairs exists, is not later permitted (is estopped) to deny that if the other person has acted to his detriment in reliance on that state of affairs and the denial would cause damage (usually financial loss) to that third party (Law of Agency, 2018).

There is no special rule peculiar to this type of agency. It is just aimed to show that agency contracts are not always expressly made, but very often may be inferred from the circumstances by the court. An implied contract 
differs from an express with the promise, which is expressed, wholly or in part, by conduct rather than by words (Mechem 1952). Thus, agency is implied from special circumstances of the case.

In agency arising by estoppel, the authority of the agent is described as apparent or ostensible but not actual, as it was not actually granted to the agent by the principal to act on the latter's behalf.

Regarding the doctrine of estoppel, the Restatement, Third in $\S 2.05$ gives two types of estoppel situations in agency. The first one is that the principal, while making no manifestation of authority, by conduct intentionally or carelessly caused belief that the agent was authorized. The second is that where, having no notice of such belief, the principal did not take any reasonable steps to notify third persons about the absence of authority (Restatement (Third) of Agency 2006).

First category can be regarded as an example of estoppel by representation. When the agent was negligent it will raise the initial question whether a duty of care is owed to the particular claimant. Usually the courts are willing to see an estoppel based on the breach of duty of care in the reasoning of the case but such situations are very rare in contract situations. The starting point is that individuals should often protect themselves in attempting to contract with others. The general argument would be rather dubious one; a person who chooses to act through others must take the risk of the ways in which those others act (Bower 2004). An interesting example of acting with a breach of duty of care can be seen in case MacAndrews \& Forbes Co. v. United States (1928) where the agent left a delivery order in a drawer in a public garage instead of delivering it to the truck driver. Such agent should be considered as unauthorized, since he did not follow his principal's instructions.

Second category explains cases where there is no manifestation of authority, but the conduct of the principal clearly indicates that there had been authority at an earlier time (Reynolds 2010).

According to the general rule mentioned in the Restatement, Second of Agency (1958) "acts are to be interpreted in the light of ordinary human experience". If a principal puts an agent into (or knowingly permits him to occupy) a position in which according to the ordinary habits of persons in the locality, trade or profession, it is usual for such an agent to have a particular kind of authority, anyone dealing with him is justified in inferring that he has such authority, in the absence of reason to know otherwise. The content of such apparent authority has to be determined from the facts (Cmt. C, Restatement (Second) of Agency 2013).

Restatement (Third) of Agency (2006) and the Principles of European Contract Law (2000) (hereinafter, PECL) follow the objective theory of contact (Lando, Beale 2000). Apparent authority there allows the principal to sue the third party on the basis of apparent authority. Objective theory of agency, which is derived from the objective theory of contract, states that principal's liability in contract just like ordinary liability in contract is based on his voluntary representations to third parties concerning the scope of the agent's authority (Conant 1968). It is noteworthy that if the objective theory is taken as the basis for apparent authority, the absence of reliance on the part of the third party will not be fatal to an assertion of apparent authority (Restatement (Third) of Agency 2006). The principal's representations or conduct toward third parties create for the agent a power to contract excessing his actual authority. This view of apparent authority requires neither proof of misrepresentation nor change of position in reliance thereon, and conforms to the mutuality of obligation.

So, in American law the view that the concept of apparent authority is based on the objective theory of agency prevails, which is directly derived from the objective theory of contract.

The estoppel view, in its turn, is dominant in England and much of Commonwealth countries. However, several important facts should be noted. Firstly, in all legal systems where apparent authority is based on estoppel, it 
works against the principal because there is, in fact, no contract formed and only the principal can be held liable as the concept itself prevents the principal from denying the existence of agency to a third party.

Moreover, in case with unauthorized agency the principal may experience certain problems with holding an unauthorized agent liable for the acts performed on the principal's behalf. The concept of estoppel prevents the principal from denying the existence of agency to a third party, thus only he can be held liable for the exceeding of authority by his agent. Liability here is based on the third party's reliance and the principal's manifestations of his agent's authority. Thus, it is clear that contract and estoppel are inconsistent concepts and cannot be combined as a basis for apparent authority (Heskell v. Continental Express, Ltd. 1950).

Controversies whether the apparent authority has a contract basis or is based on estoppel are tough as in most cases elements of both contract and estoppel are present. The estoppel view is highly criticized in the United States and civilian countries, however, in practical terms, it does not matter significantly which view is preferred, as far as the principal can sue the third party both on the basis of apparent authority and ratification. Furthermore, either view must contain some manifestation of authority moving from the principal. The only practical significance is that if estoppel is the basis for apparent authority, a principal who wishes to take the benefit out of its agent's unauthorized acts must always ratify, since a cause of action cannot be found on an estoppel (Busch, Macgregor 2009 b).

Generally, whichever the view is taken, it is widely accepted that the doctrine of estoppel is one of the most useful and flexible in law and that various types of estoppel are governed by a general principle, namely that when the parties to a contract proceed on the basis of an underlying assumption engendered by the other, neither of them will be allowed to rely on the assumption when it would be unjust or unfair to do so.

The issue of determining the essence of authority still remains a bit problematic under the Ukrainian civil doctrine as there is still no unified approach developed regarding the legal nature of the agent's authority. Traditionally, authority is considered a non-material subjective right, since no actual property right or obligation of either party to the relationship corresponds to it. This, however, does not indicate the absence of a property element in the legal relations of representation in general. The agent's right to remuneration and the corresponding principal's obligation to pay it, is an element of the relationship along with the authority, but not a part of the authority itself (Tsiura 2017, 230).

Lithuania is one a few countries where the idea of apparent authority is moved to the positive law. Paragraph 9 of Article 2.133 states that where an agent acted in excess of his powers but in the manner which gave to a third person serious grounds to think that he was concluding a contract with a duly authorised agent, the contract shall be obligatory to the principal, except in cases where the other party to the contract was aware or had to be aware that an agent was exceeding his powers.

\section{The elements of apparent authority}

Apparent authority is described as one of the main problems of agency institution (Stoljar 1961). A good definition of the doctrine of apparent authority was presented by the Restatement Third of Agency (2006) as the power held by an agent or other actor to affect a principal's legal relations with third parties when a third party reasonably believes the actor has authority to act on the principal's behalf and that belief is traceable to the principal's manifestations. 
Therefore, the third party has to rely upon the principal's manifestation of the agent's authority, which may go beyond the authority actually communicated by the principal to the agent (Müller-Freienfels 1957).

One more excellent description of the concept was given by the court in the AAA Tire opinion. It was explained that the concept of apparent authority only comes into play when the agent has acted beyond his actual authority and has no permission whatsoever from his principal to act in such a manner. The principal will be bound for such actions if he has put his agent in such a position or has acted in such a manner as to give an innocent third person the reasonable belief that the agent has authority to act for the principal. The facts and circumstances of each case must be examined to determine the reasonableness of the third party's belief. One must look from the viewpoint of the third person to determine whether an apparent agency has been created. In transactions between businessmen, the nature of the business, customs and usages within the trade can be important factors to be considered (Holmes and Symeonides 1999, 26).

Denning L. J. correctly pointed out that ostensible or apparent authority is the authority of an agent as it appears to others (Hely-Hutchinson v. Brayhead Ltd 1968). This usually happens when the principal expressly or by any other conduct makes the third party to believe that he consents to have the act performed on his behalf by the other person. If the third party with a reasonable belief relies on these manifestations and contracts with the agent on this ground, the principal is considered to be bound.

From the definition of apparent authority, certain conditions may be traced. As Slade L. J. observed in Rama Corporation Ltd v. Proved Tin and General Investments Ltd (1952) that one cannot call apparent authority unless three requirements are met: 1) a representation must have been made to the third party in order to show that the agent has authority to act on behalf of the principal.; 2) a reliance on the representation; 3) an alteration of third party's position resulting from such reliance.

Manifestations of authority show the third party that the agent is duly authorized to act on the principal's behalf. This may be made by words (oral or written) or by conduct. Authority may be also contained in a separate written document. Even though the third party has to check all the manifestations of agent's authority, he cannot know about all the details of the agent's internal authorization. Therefore, there is always a risk that the agent was not authorized to act.

However, there is a view that private restrictions made by the principal to his agent cannot effect the third party's reliance on the manifestation of authority. This was mentioned in the case Harrison Exp. (1893) where an agent had authority to apply for the shares on a particular day, however in a separate document it was stipulated that the acceptance of an offer has to be communicated to the principal. This was not done. For the reason that the contractor was unaware of the private restriction, he could rely on the document, which was presented, and the principal was estopped from denying that the agent has unrestricted authority to act on his behalf.

Authority may be implied either from the agent's status (spouse, employee) that under normal conditions would lead to the conferral of authority, or earlier declared authorization that was revoked later internally by the principal. Representation may also be implied from the principal's conduct, especially when the agent performs acts that fall within his 'usual authority' that is inferred from the ordinary course of business. In United Bank of Kuwait Ltd v. Hammoud (1988) the court of appeal held that in each case it was a matter of deciding whether the giving of the undertaking by the agent was an act for carrying on, in the usual way, business of the kind conducted by a firm of solicitors. Moreover, it was decided that in the ordinary course of business a solicitor does not receive money or a promise from a client for giving an undertaking to a third party. 
The International Journal

ENTREPRENEURSHIP AND SUSTAINABILITY ISSUES

ISSN 2345-0282 (online) http://jssidoi.org/jesi/

2018 Volume 6 Number 2 (December)

http://doi.org/10.9770/jesi.2018.6.2(13)

Countries with civil law order have accepted an approach that focuses rather on the agent's appearance of authority in certain circumstances. In France and Belgium, for instance, liability was historically based on tort, depending on the proof of the principal's fault based on the doctrine l'apparence.

Such appearance of authority may commonly take the form of appointing the agent to the position, which implies to have certain authority. Under the conclusions made in Freeman \& Lockyer v. Buckhurst Park Properties Ltd (1964) a corporation, being a fictitious person can act only through agents with actual authority conferred by the corporation in order to make the representation on its behalf. According to the view of the Restatement (Third) of Agency (2006) acting with an actual authority means that "at the time of taking action that leads to legal consequences for the principal, the agent reasonably believes, in accordance with the principal's manifestations to the agent, that the principal wishes the agent so to act." Such "actual" authority can be delegated to the agent/employee under the memorandum or articles of association in order to permit him or her to act in the management, and thereby to manifest having the proper authority to enter on behalf of the corporation into contracts of a kind which are authorized in the ordinary course of such business.

Consequently, in cases where the agent has no actual authority conferred by the corporation to act on its behalf, the contractor cannot rely upon such agent's representation at all. When apparent authority arises with companies, these representations are made through its properly authorized officers or through one of its bodies such as the board of directors (Freeman and Lockyer v Buckhurst Park Properties (Mangal) Ltd 1964).

Under Ukrainian legal doctrine, the issue whether employees can be considered as agents, acting on behalf of their employer, is still debatable. The main problem is that Ukrainian law does not possess such a legal category as "apparent authority", thus, different opinions are present. Some scholars are convinced that the agent may be granted an authority by appointing to a certain position which authorizes him to perform legal acts on behalf of that enterprise or institution ex officio without any other documents. Article 39(10) of the Law of Ukraine "On Limited liability companies"(2018) states that "the sole executive body of the company or the chairman of the collegial executive body of the company may act on behalf of the partnership without power of attorney. The Charter of the partnership may provide the possibility for each or some members of the collegial executive body to act on behalf of the partnership without a power of attorney or the possibility of all or individual members of the executive body to act on behalf of the partnership without a power of attorney exclusively together". Such an approach implies that the employment contract is the basis for the agent's authority to arise when appointing a person to a position in enterprise, institution or organization (sellers, cashiers, etc.) (Tsiura 2017, 254).

Others, however, agree that employers, acting within the scope of employment cannot be considered as agents, since they carry out activity of the legal entity itself, so the requirement that the agent and the principal have to be two independent subjects is not fulfilled in this case. In this context, Art. 1172 of the Civil Code of Ukraine (2003) (hereinafter CCU) must be considered, according to which, if the activity of the employee during the performance of his official duties caused damage to third parties, the responsibility will be borne by the legal entity (employer) as for their own actions. In this regard, an employment contract cannot be considered as the basis for the establishment of representative relations (Domanova 2006, 141). However, when the employee is duly authorized to carry out acts on behalf of a legal entity beyond the scope of his employment, he will become an agent of the legal entity. In this case, the employee will be granted authority and the relations of representation would arise.

Consequently, we can conclude that an employment contract cannot be considered as the basis for representation in civil law, since the employee acting on behalf of the company is regarded as a part of the legal entity and under the "separation theory" accepted by Ukrainian legislator, principal and agent have to be separate legal personalities. 
Thus, in order to create an agent's "apparent" authority by permitting the agent to act in the management or conduct the principal's business, the board of directors has to delegate an "actual" authority to the agent under the memorandum or articles of association in order to permit him or her to represent the corporation to third parties, enter into contracts which are authorized by the principal and are permitted in the ordinary course of such business (Freeman and Lockyer v Buckhurst Park Properties (Mangal) Ltd 1964).

A reliance on the representation means that the causal link must be established between the representation and the third party's actions. As Parker L. J. remarked in Bedford Insurance Co Ltd v. Institutio de Resseguros Brasil (1999): "A person relying on ostensible authority has...to show that he relied on the representation of the principal, and none of the insured or their brokers was called to testify to this effect. The documents certainly suggest that they could very well have done so, but I am not prepared to hold that they did so. The brokers concerned were few and, with one exception, were not called. The one who was called merely confirmed his proof and this contained no relevant evidence. In the circumstances of this case, where a number of documents were clearly shown to have created, and deliberately to have created, a false impression, oral evidence was, in my judgment, required".

As a result, for apparent authority to arise, it is important to establish third party's good faith when entering into a contract with the agent (Munday, 2010). Third parties acting in a good faith are entitled to rely on manifestations of agency, even if they suspect the agent of acting without authority (Müller-Freienfels 1957).

In contrast to the common law view on apparent authority, the continental legal systems have evolved less doctrinaire solutions to the discussed topic; however, all of them have something in common which is to protect those who in a good faith rely on the manifestation of authority.

Continental courts, in their turn, go further in their understanding of apparent authority and offer to make good faith the determinative factor. Such countries as France, Belgium and the Netherlands base their doctrine on the protection of the third party's reasonable (legitimate) belief (Banque Canadienne Nationale 1963). While assessing the legitimacy of the third party's belief, the court will look on certain circumstances of the case (such as employment, education) that would show whether the third party was more likely to fall victim to the appearance of agent's authority. In addition, agent's professional status and behavior will be assessed by the court in order to find out whether he could lead the third party to believe in the presence of authority. German law does not contain an expressly mentioned requirement of the reasonable belief, but it seems unlikely that a court would allow a third party to invoke apparent authority where the belief of the third party was not reasonable. General provision is contained in BGB (2003) that protects the good faith purchaser of movable property.

This requirement is also present in the Article 232 of the CCU (2003). To secure himself, the third party has to check whether the agent is duly authorized before concluding the contract. A representative may be mistaken as to the limits of his authority. In this case, he cannot be held liable for damages suffered by a third party. Therefore, it is of particular importance for the third party to check the agent's authority, otherwise, the third party will be considered as such that had deliberately entered into a relationship with the agent, knowing that the latter acted outside the scope of his authority or beyond the scope of warranty of authority, and, therefore, the agreement, should be considered null (Шершеневич 1907).

The alteration of position may only happen when the third party enters into the contract with the principal. Sometimes, in order to rely upon the doctrine of estoppel, the courts require the evidence that the party has acted to his detriment. As Lord Robertson declared in George Whitechurch Ltd v. Cavanagh (1902): 
The International Journal

ENTREPRENEURSHIP AND SUSTAINABILITY ISSUES

ISSN 2345-0282 (online) http://jssidoi.org/jesi/

2018 Volume 6 Number 2 (December)

http://doi.org/10.9770/jesi.2018.6.2(13)

"My Lords, the case of the respondent is one of the estoppel, and it is an essential element in such cases that the person to whom the representation was made has suffered loss by acting upon it; or, to put it in different way has altered his position to his detriment by acting on the representation."

Nevertheless, there are still many courts that require only alteration. Thus, the Diplock L. J. declares in Freeman \& Lockyer (1964) that: "the representation, when acted upon by the contractor by entering into a contract with the agent, operates as an estoppel, preventing the principal from asserting that he is not bound by the contract. It is irrelevant whether the agent had actual authority when entering into the contract or not".

After such statements, the question whether alteration is a separate requirement from reliance appears. Under the common law doctrine of apparent authority, a principal is considered to be bound under the contract when the bona fide third party has acted in reliance on agent's manifestation of authority.

Unless all conditions are met, there is a danger that the principal would be able to resile from an unauthorized contract entered into by his agent under no excuse how reasonable it was for the third party to assume that the agent acted with a due authority. In other words, the third party should always bear the risk that the agent acts without authority. Such a risk, however, must be apportioned between the principal and the third party, with the view on every individual factor in determining who must suffer consequences in a particular case, since an agent acting without authority is not personally responsible (Müller-Freienfels 1957). This compromise is the subject of the doctrine of apparent authority.

Under the doctrine of apparent authority, the third party is allowed to sue the principal. However, in case the principal is willing to sue the third party, he is not able to rely on apparent authority, since he must understand that his agent did not have enough powers to act. Also, the principal is unable to claim the benefit of any estoppel that arises from the principal's own acts.

The question also arises whether and to what extent the agent's power to bind his principal is affected by the death of the principal (Müller-Freienfels 1957). Is it possible to speak about possibility to call for apparent authority in this case?

According to the traditional English view, revealed in the prominent case Campanari v Woodburn (1854), principal's death automatically terminates agent's powers, irrespective of whether the agent or the third party knew or should have known about such an event. The origin of the rule may be found in the provision of the "fiction of identity" concept between the principal and the agent, but today the prevailing argument is that what a dead man cannot himself do, he cannot do through another, because in this case one of the essential features necessary for concluding a contract would be missed, particularly the so-called requirement of meeting of minds (Müller-Freienfels 1957).

Speaking about soft law instruments in the field of private law, they provide certain regulation on this topic that tried to combine the most characteristic features of both legal families. These acts also contain certain provisions on the question of apparent authority. In general, UNIDROIT Principles (2010) accept the English law position in regard to the apparent authority where the agency is based on estoppel, whereas the European Principles try to enforce the continental approach.

Under the European Principles (2000), both the principal and agent are bound to each other by acts within the agent's apparent authority as much as by acts within its actual authority (Lando, Beale 2000). Apparent authority there may be invoked by the third party only in case the third party had a reasonable belief that the agent had sufficient authority. 
Under the UNIDROIT Principles (2010), if the principal wants to rely on the doctrine of apparent authority, there is a requirement to ratify the unauthorized act. Under the European Principles (2000), ratification is confined to direct representation, since indirect agency implies the agent not acting in the name of the principal at all.

The issue of unreciprocated power to hold the other party bound to the contract has also to be seen in the context of apparent authority. Under both English law and the UNIDROIT Principles (2010), the principal is bound under the contract even in case the agent's act fell outside the scope of the actual authority, provided it was performed within the scope of his apparent authority. Under the European Principles (2000), an act within the agent's apparent authority automatically binds both principal and third party so no question of speculation can arise (Bennett 2006).

Mixed legal systems have a unique requirement that the representation must have been of such nature that the principal could reasonably have expected it to be acted on (Monzali v. Smith (1929). This approach is criticized by the common law representatives as such an objective element may appear to be unjust for innocent principals.

\section{Conclusions}

The law of agency cannot be limited to cases where the agent possesses an express or implied actual authority. In order to ensure the sustainability in business, an agent always needs to have a certain degree of discretion which would allow him to act outside the scope of the actual authority. At the most common sense, apparent authority can be described as cases when the principal did not authorize or provided limited rights to the agent to act in his own name, but because of the actions by the principal or other circumstances related to him a third party reasonably and fairly believes that the agent has required authorization.

It is important to distinguish apparent authority from implied authority. Implied authority arises from the factual circumstances under which the agent is acting and is considered a part of actual authority. It means that contrary to the case of apparent authority the actions by the agent with implied authority do not mean unauthorized agency

Since the doctrine of apparent authority is an essential element of unauthorized agency, it is deemed to protect the interests of a third party who reasonably believed that the agent was duly authorized to act. Although the agent has only the appearance of authority, but no actual authority to act, he is still capable to bind the principal under the contract with third party, if the latter relied on such manifestation. Manifestations of authority sometimes may go beyond the authority actually communicated by the principal to the agent.

The legal foundation of the doctrine of apparent authority is considered to be controversial. English view that was later followed by UNIDROIT Principles regards the concept of estoppel as the basis. Continental approach sticks to the leading view that the concept of apparent authority is based on the objective theory of agency, which is directly derived from the objective theory of contract, since the English position causes certain problems with holding an unauthorized agent liable for the acts performed on the principal's behalf.

For apparent authority to arise, three conditions must be met: 1 . A representation must have been made to the third party in order to show that the agent has authority to act on behalf of the principal; 2 . A third party's reliance on the agent's representation; 3. An alteration of third party's position resulting from such reliance.

Unless all conditions are met, the third party should always bear the risk that the agent acts without authority and the principal would be able to resile from such a contract. 


\section{References}

Amalgamated Investment \& Property Co. Ltd v. Texas Commerce International Bank Ltd [1982] 2 QB 73 at 122.

Banque Canadienne Nationale D 1963, J 277, Cass Ass Plen 12-12-1962.

Bedford Insurance Co Ltd v. Institutio de Resseguros Brasil [1999] 2 AC 349. Cited at: http://www.uniset.ca/other/css/1985QB966.html.

Bennett, H. 2006. Agency in the Principles of European Contract Law and the UNIDROIT Principles of International Commercial Contracts (2004), Uniform Law Review 11: 771-793. https://doi.org/10.1093/ulr/11.4.771.

Bürgerliches Gesetzbuch (BGB): Neugefasst durch Bek. v. 2.1.2002 I 42, 2909; 2003, 738; zuletzt geän dert durch Art. 16 G v. 29.6 .2015 I 1042. Access mode: http://www.gesetze-im-internet.de/bundesrecht/bgb/gesamt.pdf

Bowstead \& Reynolds on Agency / W. Bowstead, F. M. B. Reynolds / General editor Peter G. Watts. [20. ed.] London: Sweet and Maxwell, 2014. 944 p.

Campanari v Woodburn (1854) 15 CB 400.

Civil Code of the Republic of Lithuania. 2000. Valstybès žinios No. 74-2262.

Civil Code of Ukraine of January 16, 2003 // Information from the Verkhovna Rada of Ukraine. 2003. No. 40-44. Available on the Internet at: http://zakon5.rada.gov.ua/laws/show/435-15.

Conant, M, Objective. 1968. Theory of Agency: Apparent Authority and the Estoppel of Apparent Ownership, 47 Neb. L. Rev. 678. Access mode: http://digitalcommons.unl.edu/cgi/viewcontent.cgi?article=2532\&amp; context=nlr.

Cook W. W., "Agency by Estoppel' (1905) Colum L Rev 536.

Domanova Iryna. 2006. "The institute of voluntary representation in the civil law of Ukraine.” Doctoral dissertation, Taras Shevchenko National University of Kyiv.

Finogentova, O.; Tokarev, V.; Petrenko, M.; Primak, T. 2018. Acceptance criterion of state coercion in contemporary society, Entrepreneurship and Sustainability Issues 6(2): 820-829. http://doi.org/10.9770/jesi.2018.6.2(23)

Freeman \& $\quad$ Lockyer $\quad$ (A $\quad$ Firm) $\quad$ v $\quad$ Buckhurst $\quad$ Park $\quad$ Properties $\quad$ (Mangal) $\quad$ Ltd $\quad\left(\begin{array}{lllllll}1964 & 2 & \text { QB } & 480 .\end{array}\right.$ http://www.casebooks.eu/contractLaw/Chapter27/excerpt.php?excerptId=4775.

Fridman G.H. The Law of Agency 7th ed. Toronto: Butterworths Canada, 1996 - 434 p.

George Whitechurch Ltd v. Cavanagh (1902) AC 117, 135.

Harrison Exp (1893) 69 LT 204.

Hely-Hutchinson v. Brayhead Ltd (1968) 1 Q.B. 549 at 583.

Heskell v. Continental Express, Ltd. (1950) 1 All E.R. 1033, 1044.

Holmes, Wendell H. and Symeonides, Symeon C. (1999). Representation, Mandate, and Agency: A Kommentar on Louisiana's New Law, Journal Articles, p. 26. Access mode: http://digitalcommons.law.lsu.edu/faculty scholarship

International Institute for the Unification of Private Law. 2010. UNIDROIT Principles of International Commercial Contracts. Available on the Internet: http://www.unidroit.org/english/principles/contracts/principles2010/integralversionprinciples2010-e.pdf. 
The International Journal

ENTREPRENEURSHIP AND SUSTAINABILITY ISSUES

ISSN 2345-0282 (online) http://jssidoi.org/jesi/

2018 Volume 6 Number 2 (December)

http://doi.org/10.9770/jesi.2018.6.2(13)

Lando, O.; Beale, H. 2000. Principles of European contract law. The Hague: Kluwer Law International.

Law of Agency 2018. Available on the Internet: https://www.casrilanka.com/casl/images/stories/EDBA/law\%20of\%20agency.pdf.

Law of Ukraine “On Limited liability companies” 06.02.2018 № 2275-VIII Available at: http://zakon0.rada.gov.ua/laws/show/1576-12.

MacAndrews \& Forbes Co. v. United States 23 F 2d 667 (1928).

Mechem, Floyd R. (Floyd Russell), Outlines of Agency (Callaghan \& Company, Chicago; 4th edition (1952).

Monzali v. Smith (1929) AD 382.

Munday, R. Agency: Law and Principles (First Edition -New York: Oxford, 2010-369 p.).

Powell R. The Law of Agency- London: Pitman, 1951. 355 p.

Rama Corporation Ltd v. Proved Tin and General Investments Ltd (1952) 2 QB 147, 149-50.

Restatement (Third) of Agency, American law Institute. St. Paul, Minn.: American Law Institute Publishers, 2006. Available on the Internet at: http://www.law.uh.edu/assignments/spring2013/30114-first.pdf.

Restatement of the Law, Second, Agency. American Law Institute. St. Paul: West Publishing Co., 19582005.

Access mode: http://www.law.uh.edu/assignments/spring2013/30114-first.pdf.

Reynolds, F.M.B. Bowstead \& Reynolds on Agency. [18th ed.]. London: Sweet \& Maxwell, 2010. 944 pp.

Spencer Bower, The law relating to estoppel by representation/ by Piers Feltham, Daniel Hochberg, and Tom Leech. - 4th ed. - London: LexisNexis UK, 2004. 531 p.

Stoljar, S. J. 1961. The law of agency: its history and present principles. Sweet \& Maxwell.

The unauthorized agent: perspectives from European and Comparative law //Ed. by Danny Busch and Laura J Macgregor Cambridge: Cambridge University Press, 2009. 480 pp.www.cambridge.org

Tsiura Vadim. 2017. "The representation institute in the civil law of Ukraine". Doctoral dissertation, Taras Shevchenko National University of Kyiv.

United Bank of Kuwait Ltd v. Hammoud (1988) 1 WLR 1063.

Wolfram Muller-Freienfels The Law of Agency (American Journal of Comparative Law. 1957, p. 170-173 [access mode]: https://www.britannica.com/topic/agency-law.

Shershenevich G. F. Russian Civil Law Textbook (Шершеневич Г. Ф. Учебник русского гражданского права) (1907 г.)/ Г. Ф. Шершеневич; вступ. ст. Е. А. Суханов. - М.: Фирма «СПАРК», 1995. - 556 с. 
The International Journal

ENTREPRENEURSHIP AND SUSTAINABILITY ISSUES

ISSN 2345-0282 (online) http://jssidoi.org/jesi/

2018 Volume 6 Number 2 (December)

http://doi.org/10.9770/jesi.2018.6.2(13)

Vaidas JURKEVIČIUS is an associate professor at Mykolas Romeris University and Vilnius Gediminas Technical University. He obtained PhD degree in law from Mykolas Romeris University in 2014 (the topic of PhD Thesis was related to the unauthorised agency from a comparative perspective). His research interests include business law, comparative law and agency law. He published 13 articles in peer-reviewed journals, 3 textbooks (one of them was recognised as the best in the academic year of 2015/2016) and made 6 presentations in international conferences. He also took part in 11 internship programs in Canada, Finland, Switzerland, Sweden, Denmark, Greenland, the United Kingdom, Denmark, Italy and Austria. His internship at the University of Geneva was rated as one of the 5 most successful.

ORCID ID: orcid.org/0000-0002-1443-3427.

Yuliia POKHODUN is a PhD student at Mykolas Romeris University. She obtained a qualification of Master of Law at the Taras Shevchenko National University of Kyiv, Ukraine and at Mykolas Romeris University, Vilnius, Lithuania in 2018 (under the joint study programme "Private Law"). Her PhD topic is related to aligning of interests in international commercial agency from the perspectives of civil law and common law. Her research interests include agency law, contract law and comparative law.

ORCID ID: orcid.org/0000-0002-8548-7131.

Register for an ORCID ID:

https://orcid.org/register

Copyright (C) 2018 by author(s) and VsI Entrepreneurship and Sustainability Center

This work is licensed under the Creative Commons Attribution International License (CC BY).

http://creativecommons.org/licenses/by/4.0/

(c) (7) Open Access 